\title{
Reversing the immune ageing clock: lifestyle modifications and pharmacological interventions
}

\author{
Niharika A. Duggal
}

Received: 27 June 2018/Accepted: 16 September 2018/Published online: 29 September 2018

(C) The Author(s) 2018

\begin{abstract}
It is widely accepted that ageing is accompanied by remodelling of the immune system, including reduced numbers of naïve T cells, increased senescent or exhausted $\mathrm{T}$ cells, compromise to monocyte, neutrophil and natural killer cell function and an increase in systemic inflammation. In combination these changes result in increased risk of infection, reduced immune memory, reduced immune tolerance and immune surveillance, with significant impacts upon health in old age. More recently it has become clear that the rate of decline in the immune system is malleable and can be influenced by environmental factors such as physical activity as well as pharmacological interventions. This review discusses briefly our current understanding of immunesenescence and then focuses on lifestyle interventions and therapeutic strategies that have been shown to restore immune functioning in aged individuals.
\end{abstract}

Keywords Ageing - Immunesenescence · Inflammaging

N. A. Duggal $(\square)$

MRC-Arthritis Research UK Centre for Musculoskeletal Ageing Research, Institute of Inflammation and Ageing, Birmingham University, Birmingham, UK

e-mail: n.arora@bham.ac.uk

\section{Immune ageing and health}

Over the past 250 years life expectancy has increased dramatically and is still increasing at 2 years per decade in most countries. Advancing age is accompanied by a compromised ability of older adults to combat bacterial and viral infections (Gavazzi and Krause 2002; Molony et al. 2017a, b), increased risk of autoimmunity (Goronzy and Weyand 2012), poor vaccination responses (Del Giudice et al. 2017; Lord 2013) and the re-emergence of latent infections to produce conditions such as shingles (Schmader 2001). All of this contributing towards increased morbidity and mortality in older adults (Pera et al. 2015) and indicative of reduced immunity.

Another universal feature of physiological ageing is an increase in circulating levels of pro-inflammatory cytokines (IL-1 $\beta$, IL-6, IL8, TNF $\alpha$, IFN $\gamma$, and CRP) termed "Inflammaging" (Franceschi et al. 2007). Importantly, a strong association has been reported between elevated pro-inflammatory cytokine levels in older adults and mortality (Cohen et al. 2003), frailty (Cesari et al. 2004), age-related chronic diseases (Ershler and Keller 2000) and cognitive impairment (Yaffe et al. 2003). Inflammaging is multifactorial with some of the factors proposed to contribute to inflammaging including: lifetime antigenic load resulting in oxidative damage; increased DNA damage, accumulation of senescent cells, increased visceral adipose tissue; decline in sex hormones and 
reduced immune regulation (Baylis et al. 2013; Singh and Newman 2011).

Altered immunity with age is the result of remodelling of both the innate and adaptive arms of the immune system, collectively termed immunesenescence. Delaying or reversing the effects of ageing on the immune system could be extremely beneficial in maximising health and improving quality of life in older adults (Dorshkind et al. 2009). For the cells of the innate immune response the literature is clear that their numbers increase with age but their function upon challenge with pathogens declines. Thus ageassociated defects have been observed in neutrophils, monocytes/macrophages, NK cells and dendritic cells (Fig. 1). Neutrophils are the primary immune defence against bacterial and fungal infections and recent studies have revealed that in addition to the well documented reduction in phagocytosis and ROS generation, these cells also show reduced chemotaxis to a range of stimuli (Sapey et al. 2014) and a reduced ability to extrude their DNA as NETs to entrap bacteria extracellularly (Hazeldine et al. 2014). Additionally, an age-associated reduction in TLR1 expression on neutrophils has been associated with reduced chemokine (IL8) production, reduced rescue from apoptosis and lower expression of activation markers, resulting from reduced bioenergetics in neutrophils (Qian et al. 2014).

Circulating monocytes play a critical role in defence against invading pathogens being early responders to infection and able to act as antigen presenting cells. Ageing affects the distribution of monocyte subsets with a decline in classical monocytes (CD14 ${ }^{+\mathrm{ve}} \mathrm{CD} 16^{-\mathrm{ve}}$ ) and increase in intermediate $\left(\mathrm{CD} 14^{+\mathrm{ve}} \mathrm{CD} 16^{+\mathrm{ve}}\right)$ and non-classical monocytes $\left(\mathrm{CD} 14^{+\mathrm{ve}} \mathrm{CD} 16^{++\mathrm{ve}}\right.$ ) occurs with age (Seidler et al. 2010). Interestingly, non-classical monocytes express high levels of miR-146a and exhibit a senescence associated secretory phenotype (SASP), contributing towards inflammaging (Ong et al. 2018). Also, ageassociated changes in platelets also contribute towards inflammatory cytokine production by monocytes (Campbell et al. 2018). However, monocyte cytokine secretion in response to stimulation via TLRs is greatly reduced with age (Metcalf et al. 2017). A notable exception is TLR5 expression that has been reported to increase with age, offering an opportunity to develop improved vaccines for older adults (Qian et al. 2012). Retinoic acid inducible gene 1 (RIG-1) like receptors play a key role in recognition of viral nucleic acids and older human monocytes have intact RIG1 signalling to activate pro-inflammatory cytokines but have a diminished IFN response (Pillai et al.

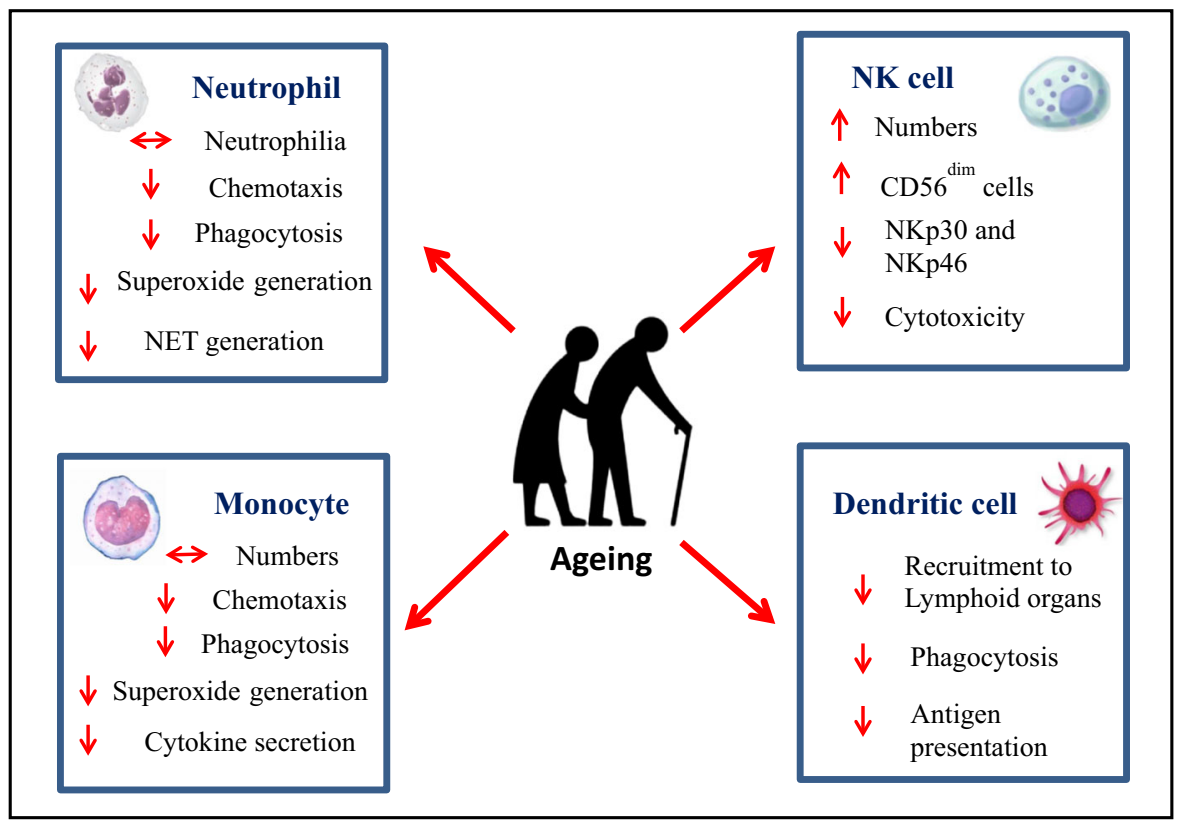

Fig. 1 Age related alterations in innate immune cells 
2016; Molony et al. 2017a). Cytosolic dsDNA receptor AIM2 triggers the inflammasome and is important for control of virus infections (Guo et al. 2015). Recently, defects in AIM2 expression have been reported in monocytes of older adults, impairments in caspase 1 activation upon stimulation of AIM2 has been associated with reduced IL1 $\beta$ secretion (Wang et al. 2016). These alterations in innate immune responses to pathogens with ageing have consequences for the ability of older adults to respond to an infectious challenge. Other monocyte functions such as wound repair (Sebastián et al. 2005) and clearance of apoptotic cells (Aprahamian et al. 2008) are also compromised in older adults.

Dendritic cells play a key role in initiating pathogen-specific adaptive immune responses and have been divided into two subsets-myeloid DCs and plasmacytoid DCs. A reduction in plasmacytoid DCs and unaltered frequency of myeloid DCs have been reported in older adults (Garbe et al. 2012). Recent data in this field has led to further division of myeloid DCs into two subsets; CD1c ${ }^{+v e}$ and CD141 $1^{+-}$ ve mDCs. Ageing is accompanied by a decline in peripheral $\mathrm{CD} 141^{+\mathrm{ve}} \mathrm{DCs}$, whereas the $\mathrm{CD} 1 \mathrm{c}^{+\mathrm{ve}}$ mDCs remain unaltered (Agrawal et al. 2016). Age associated impairments occur in DC recruitment to lymphoid organs post antigen exposure which has been associated with mitochondrial dysfunction (Chougnet et al. 2015). Surprisingly, the age associated ability of DCs to phagocytose C.albicans remains intact (Do Nascimento et al. 2015). Also, the ability of DCs to induce $\mathrm{T}$ cell proliferation and IFN $\gamma$ secretion is impaired in older adults, resulting in impairments in vaccine responses (Panda et al. 2010; Sridharan et al. 2011). Another age associated dysfunction of DCs is in their ability to efficiently activate NK cells which is likely to contribute to impaired tumour immunity (Guo et al. 2014).

NK cells are innate cytotoxic lymphocytes that play an essential role in defence against viral infections and malignancies and they also kill senescent cells thus contributing to delaying the ageing phenotype (Sagiv et al. 2013). Ageing is accompanied by an increase in NK cell numbers, due to expansion of CD56 ${ }^{\mathrm{dim}} \mathrm{NK}$ cells (Le Garff-Tavernier et al. 2010; AlmeidaOliveira et al. 2011). CMV seropositivity and proinflammatory status (Campos et al. 2014) are contributors towards altered NK cell subset distribution. The expression of NK cell receptors; NKp46 ${ }^{\text {and }} \mathrm{NKp} 30$ has been shown to decline with age, whereas NKG2D expression remains unaltered (Solana et al. 2014), as NKG2D is required for the killing of senescent cells (Sagiv et al. 2016) this may affect the killing ability of NK cells towards senescent cells, though this has not yet been shown. In this context, NK cell cytotoxicity towards cancer cells is mediated by granule exocytosis and is reduced with age (Almeida-Oliveira et al. 2011; Hazeldine et al. 2012), due to reduced release of perforin (Hazeldine et al. 2012). In contrast, NK cell mediated antibody dependent cell cytotoxicity (ADCC) is preserved with age (Lutz et al. 2005).

Myeloid derived suppressor cells (MDSCs) are known to play an important role in suppression of $\mathrm{T}$ cell responses (Gabrilovich and Nagaraj 2009). Importantly, ageing is accompanied by an increase in MDSCs, which has been linked with a higher incidence of cancer and chronic inflammation in aged individuals (Enioutina et al. 2011). In the adaptive immune system, the effects of age are also significant (Fig. 2). The thymus is devoted to T lymphocyte differentiation and maturation and ageing is associated with atrophy of the thymus (Mitchell et al. 2010). In humans, thymic atrophy involves a decrease in both stromal and thymocyte cellularity with infiltration of adipocytes, loss of tissue organisation, reduced levels of cytokines and hormones essential for thymopoiesis (e.g. IL-7, KGF and Ghrelin) and upregulation of thymosuppressive cytokines (e.g. IL-6, TNF $\alpha$ ) with age (Palmer 2013; Ventevogel and Sempowski 2013). The net outcome of thymic involution is reduced naïve T cell output (Haines et al. 2009) which compromises the ability to respond to new pathogens and vaccines. Other hallmarks of $\mathrm{T}$ cell immunesenescence include: accumulation of $\mathrm{CD} 28^{-\mathrm{ve}} \mathrm{CD} 57^{+\mathrm{ve}} \mathrm{T}$ cells with shortened telomeres and reduced proliferative capacity (Strioga et al. 2011), which also acquire NK cell receptors such as KLRG1 (Weng et al. 2009) increasing risk of autoimmune responses; skewing of $\mathrm{T}$ cell responses towards Th17 cell differentiation (Ouyang et al. 2011). Regulatory CD ${ }^{+\mathrm{ve}} \mathrm{CD} 25^{+\mathrm{ve}} \mathrm{Foxp} 3^{+\mathrm{ve}} \mathrm{T}$ cells play a pivotal role in maintaining immune homeostasis by suppressing immune responses. Ageing is associated with an increase in the frequency of $\mathrm{T}_{\text {regs, }}$, which correlates with increasing incidence of cancer in older adults (Hou et al. 2017).

As with $\mathrm{T}$ cells there is a decline in the frequency of naïve $\mathrm{B}$ cells $\left(\mathrm{CD} 27^{-\mathrm{ve}} \mathrm{IgD}^{+\mathrm{ve}}\right)$ and an increase in memory $\mathrm{B}$ cells has also been reported (Colonna- 


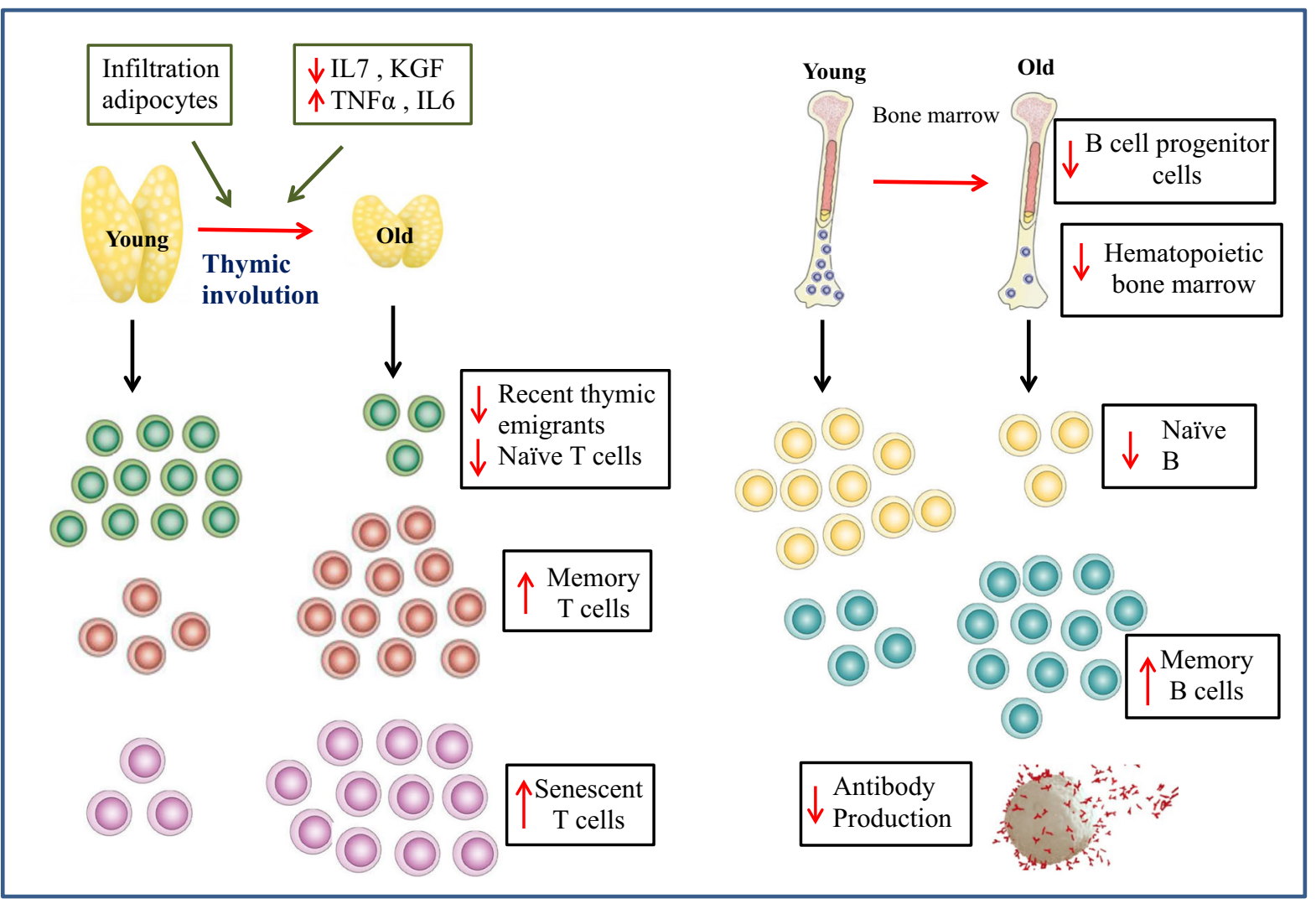

Fig. 2 Age related alterations in adaptive immune cells

Romano et al. 2006) (Fig. 2). Ageing is accompanied by poor vaccination responses, likely due to reduced $\mathrm{B}$ cell and T cell activity (Siegrist and Aspinall 2009). Older adults generate tenfold fewer antibody secreting cells relative to young individuals on antigenic stimulation (Kogut et al. 2012). Additionally, the antibodies produced by aged B cells have lower affinity and fewer antibodies are pathogen specific (Howard et al. 2006). A decline in CD4 T cell and dendritic cell functioning, along with intrinsic changes in $\mathrm{B}$ cells resulting in age-associated reduction in number and size of germinal centres are all contributing factors towards the decline in antibody production by older individuals with age (Frasca and Blomberg 2009). Further, an age associated numerical and functional deficit in a novel subset of immunosuppressive $\mathrm{CD} 19^{+\mathrm{ve}} \mathrm{CD} 24^{\mathrm{hi}} \mathrm{CD} 38^{\mathrm{hi}} \mathrm{B}$ cells has been recently reported, which might be a factor contributing towards increased risk of systemic autoimmunity with advancing age (Duggal et al. 2012).
As the immune system does not operate in isolation and can be modified by a broad range of environmental signals, we now consider how modification of lifestyle could be used to improve on the reduced immune responses of older adults.

\section{Impact of lifestyle factors on immunesenescence and inflammaging}

Physical activity

Regular physical activity has been associated with major health benefits including; reduced risk of cardiovascular diseases, diabetes, stroke, sarcopenia and mortality (Shepherd et al. 2015). However, ageing is accompanied by a sharp decline in both duration and intensity of physical activity and the majority of older adults fail to meet the World Health organisation (WHO) recommended guidelines of $150 \mathrm{~min}$ of 
aerobic exercise per week (World Health Organisation 2010).

Exercise in older adults has been associated with lower levels of pro-inflammatory cytokines such as IL6, TNF $\alpha$ (Gleeson et al. 2011). Physical activity exerts an anti-inflammaging effect via several mechanisms. Fat mass increases with age, which has been associated with low-grade chronic inflammation. This is due in large part to the pro-inflammatory cytokines secreted by fat, termed adipokines. Levels of proinflammatory adipokines such as leptin and visfatin increase with age whereas anti-inflammatory adiponectin decreases (Gulcelik et al. 2013). In addition, adipose tissue contains immune cells including macrophages which themselves secrete pro-inflammatory cytokines (Vieira-Potter 2014). Regular physical activity has been associated with a reduction of visceral and abdominal fat (Ross and Bradshaw 2009) resulting in a reduction of pro-inflammatory cytokine levels. Skeletal muscle itself is also a major source of cytokines, termed myokines in the physiology literature (Hoffmann and Weigert 2017). Exercising muscle transiently secretes less IL-6 and more anti-inflammatory IL-10 (Steensberg et al. 2003), providing a counter to inflammaging.

Physical activity also has direct effects on immune function, including in older adults. In aged humans intervention studies ranging from 6 weeks up to 10 months, performed 1-6 times per week have reported multiple effects on the immune system including: improved neutrophil chemotaxis (Bartlett et al. 2016) and phagocytosis (Sasaki et al. 2013; lower frequency of $\mathrm{CD} 16^{+\mathrm{ve}}$ monocytes that may be critical in reducing inflammaging (Timmerman et al. 2009); enhanced NK cell cytotoxicity (Bigley et al. 2015), mobilisation of dendritic cells (Suchánek et al. 2010), reduced memory $\mathrm{T}$ cells and increased $\mathrm{T}$ cell proliferation (Shinkai et al. 1995), increased T cell telomere length (Silva et al. 2016), improved T helper cell functioning (Shimizu et al. 2008) and immature B cell mobilisation (Turner et al. 2016). In a recent study we reported that high levels of physical activity in adulthood has a beneficial effect on thymic output likely to be a result of improved thymic microenvironment (raised levels of IL7 and lower levels of IL6). Additionally, we found the maintenance of peripheral naïve $\mathrm{T}$ cell frequency in the active older adults which was associated with higher serum IL15 (Duggal et al. 2018). Others have shown that individuals who perform regular exercise appear to be at a reduced risk of mortality from infections (Lowder et al. 2005) and participation in aerobic exercise for 3 months before the influenza vaccination improved vaccination responses in older adults (Kohut et al. 2004). However it is likely that physical activity needs to be maintained to achieve effects on vaccination responses as a study involving a 45 min brisk walk before vaccination showed no effect (Long et al. 2012). In summary, regular participation in physical activity is a noninvasive, mostly cost neutral anti-immunesenescence and anti-inflammaging therapy.

\section{Caloric restriction}

Restriction of food intake to approximately $30 \%$ of ad libitum calorie intake (caloric restriction), without malnutrition, is a robust means of increasing longevity and delaying onset of age-associated diseases in a variety of species including primates (Fontana and Partridge 2015; Mattison et al. 2017). Several of these studies have looked at the impact of CR on immunesenescence and have shown benefits including: maintenance of the thymic microenvironment, higher concentrations of circulating naïve $T$ cells, amelioration of age associated $\mathrm{T}$ cell proliferative defects and improved TCR diversity in mice (Yang et al. 2009) and monkeys (Messaoudi et al. 2006). Additionally, age associated accumulation of senescent $\mathrm{T}$ cells was not seen in calorically restricted mice (Spaulding et al. 1997). CR can also modulate the cytokine secretion profile of $\mathrm{T}$ cells, inducing a decrease in TNF $\alpha$ and IFN $\gamma$ production by $\mathrm{T}$ cells in mice (Nikolich-Zugich and Messaoudi 2005) and suppression of B cell lymphopoiesis in mice (Tang et al. 2016). However, studies investigating the impact of $\mathrm{CR}$ on infectious disease susceptibility have yielded contradictory findings. Effros et al. (1991) reported that aged CR mice could mount a vigorous response against influenza, whereas Ritz et al. showed increased susceptibility to infections in aged CR mice (2006).

$\mathrm{CR}$ also affects innate immune cells, but these effects have been less well studied and the few studies to date suggest the effects are not universally beneficial. Neutrophil function has been reported to be unaffected by CR in dogs (Greeley et al. 2006), whilst a decline in circulating NK cell frequency (Clinthorne et al. 2013) and NK cell cytotoxicity was seen in CR mice (Ritz et al. 2008). Leptin, an adipocyte secreted 
hormone plays an important role in maintaining NK cell numbers (Tian et al. 2002). Leptin levels are reduced in $\mathrm{CR}$ mice, making it a potential candidate through which immunomodulatory effects of CR are mediated (Clinthorne et al. 2013). Similar to NK cells, reductions in circulating DC numbers and DC progenitors in bone marrow have been reported in CR mice (Duriancik and Gardner 2016).

The high prevalence of centenarians and lower morbidity from age-associated diseases in Okinawans is intriguing evidence supporting the view that $\mathrm{CR}$ could also have lifespan and health span benefits in humans (Willcox et al. 2017). The Okinawans have a calorie intake that is much lower than their mainland Japanese peers, related to their beliefs that you should always leave some food on your plate at the end of a meal. Children intake approximately $60 \%$ of the recommended calories for a child in the UK and for adults this is $80 \%$ (Willcox et al. 2007). Importantly Okinawans have significantly reduced incidence of most cancers that are common in the developed world including breast, prostate and colon cancer and have lower levels of dementia (Willcox et al. 2007). There are currently no data concerning immune function in Okinawans. There are still very few rigorous clinical trials involving CR. A National Institute of Aging sponsored randomized trial of a 2 year caloric restriction regimen in healthy humans (CALERIE) revealed slowing of biological ageing as evidenced by reduced cardiovascular disease risk biomarkers and lower levels of pro-inflammatory cytokines, which has been associated with decline in body fat mass (Das et al. 2017; Ravussin et al. 2015).

Chronic nutrient excess, particularly a high fat diet leads to an increase in systemic inflammation, which over time activates immune cells promoting local chronic inflammation in metabolic cells such as adipocytes and hepatocytes (Franceschi et al. 2017). Thus, it is not surprising that $\mathrm{CR}$, which can result in a reduction in visceral body fat, may be a promising anti-inflammaging intervention. CR has been shown to reduce IL6 levels in old rhesus monkeys (Willette et al. 2010). IL6 is a known thymosuppressive cytokine and reducing its levels by CR could be a contributing factor towards improved thymic output observed in CR animals (Yang et al. 2009). Thus to date, CR has shown impact as a dietary intervention for immunesenescence in animal models but further studies are required to determine its effects on human immune ageing and especially if it is beneficial for all aspects of the immune response.

\section{Nutrition}

Optimal nutrition is an important determinant of healthy ageing and plays a significant role in maintaining immune function. Malnutrition risk significantly increases with age (Elia et al. 2008), possibly contributing to compromised immune function and increased infection susceptibility in older adults. Observational studies have examined the association between reduced expression of pro-inflammatory markers and the Mediterranean diet (low in saturated and high in monounsaturated fats mainly from olive oil, high in carbohydrates mainly from legumes and high in fibre) in healthy adults (Chrysohoou et al. 2004). A recent study with 125 older subjects, RISTOMED, has reported a similar anti-inflammaging effect of a mediterranean diet with or without supplementation with d-limonene (Ostan et al. 2016). Increased intake of specific dietary components, such as omega 3 fatty acids (Molfino et al. 2014) also has anti-inflammatory effects. Interestingly, the adoption of the mediterranean diet by older adults has also been associated improvement in immune responses, particularly dendritic cell function (Clements et al. 2017).

Another specific dietary component thought to possess immunomodulating properties are probiotics (Thomas and Versalovic 2010). Ageing is associated with a reduction in beneficial microbes in the colon including Bifidobacteria, countered by a rise in proteolytic bacteria (Pae et al. 2012). The administration of B. bifidium exerts an anti-senescence (reduced p16 expression in thymus and spleen) and antiinflammatory effects (lower IL6 and TNF $\alpha$ levels) in old mice (Fu et al. 2010). A study done on 61 healthy adults aged $>65$ years reported that probiotic consumption for 6 months increased the number of recent thymic emigrants and decreased the number of senescent CD8 CD28 ${ }^{\text {null }}$ T cells (Moro-García et al. 2013). Additionally o an improved cytotoxicity of NK cells (Gill et al. 2001) and phagocytic activity of granulocytes (Maneerat et al. 2014) has been reported with probiotic consumption for 3 weeks in healthy elderly. Probiotic supplementation for 13 weeks has also been reported to improve vaccine responses in a clinical trial done in over 200 subjects $>70$ years (Boge et al. 2009). Another trial in 1072 healthy old 
participants reported a reduced risk of respiratory infection in participants consuming fermented dairy product containing probiotics for 3 months (Guillemard et al. 2010).

Vitamin D has also emerged as a key modulator of a range of immune functions including: monocyte differentiation into macrophages, enhanced phagocytosis by macrophages, reduced production of proinflammatory cytokines by macrophages, suppression of DC maturation to promote tolerance, inhibition of Th1 and Th17 responses and regulation of B cell proliferation (reviewed in Hewison 2010; Vanherwegen et al. 2017). Vitamin D serum levels vary with the time of year but are also low in older adults (Gallagher 2013). An observational study reported a significant association between low vitamin D status and markers of inflammation in older adults (Laird et al. 2014). Although the potential of Vitamin D supplementation in reversing immunesenescence still remains largely unexplored, vitamin D supplementation has been reported to boost response to acute infections in ageassociated inflammatory disorders (Yin and Agrawal 2014) and improve macrophage antibacterial properties in chronic kidney disease (Bacchetta et al. 2014).

Zinc is a trace element required for multiple immune cell tasks including suppression of production of pro-inflammatory cytokines (IL1 $\beta, \mathrm{TNF} \alpha$ ) by monocytes/macrophages and decreasing reactive oxygen species (ROS) (Prasad 2009). A significant proportion of older adults have low serum zinc levels due to inadequate intake, impaired metabolism, infection and inflammation (Pae et al. 2012). Zinc deficiency has been reported to affect multiple immune cells and remarkably parallels changes in immune functioning with age including: impairments in neutrophil function (Haase and Rink 2009), macrophage phagocytosis (Rink and Gabriel 2000), NK cell cytotoxicity (Mocchegiani and Malavolta 2004), thymic involution (Mitchell et al. 2006), imbalance of Th1/Th2 differentiation (Prasad 2000), impairments in lymphocyte proliferation, IL2 production (Rink and Gabriel 2000) and decreased vaccine responses (Haase and Rink 2009). Zinc deficient subjects have also been shown to have greater susceptibility to pathogens (Walker and Black 2004). Importantly zinc supplementation has been shown to reduce infection incidence in older adults (Prasad et al. 2007) and has many effects indicative of reversal of immunesenescence including: improved NK cell cytotoxicity (Mocchegiani et al. 2003), modification of Th1/Th2 balance (Uciechowski et al. 2008), restoration of serum thymulin activity (Boukaiba et al. 1993) and improved vaccine responses (Duchateau et al. 1981).

\section{Pharmacological interventions to reduce immunesenescence}

\section{Caloric restriction mimetics}

Even though increasing lifespan and improving health in old age is enormously attractive to most people, a lifetime commitment to a reduced calorie diet is unlikely to be adopted at a population level. As a result, CR mimetics are being sought and several have already been identified including; Resveratrol (SIRT1 activator), Metformin (AMP kinase activator) and Rapamycin (mTOR inhibitor).

Resveratrol, a polyphenolic sirtuin activator (De la Lastra and Villegas 2005) which has been shown to extend lifespan in several species, occurs naturally in various plants including red grapes, peanuts and berries. Although there is not a vast literature on the impact of resveratrol on immunity in vivo, several in vitro studies have demonstrated immune modulating effects, these include a suppressive effect of resveratrol on neutrophil chemotaxis, superoxide generation (Cavallaro et al. 2003), T cell proliferation and cytokine production (Gao et al. 2001) and an enhancement of NK cell cytotoxicity ( $\mathrm{Lu}$ and Chen 2010). Resveratrol's immunomodulating properties are dose dependent manner, with low concentrations exerting a positive effect and higher concentrations being largely inhibitory (Falchetti et al. 2001). Additionally, anti-inflammatory effects of resveratrol have been reported in animal studies (Das and Das 2007; Tung et al. 2015). Another example of resveratrol as an anti-inflammatory agent has been highlighted in a study showing that the long-term treatment with resveratrol significantly attenuated the development of senescence-associated secretory phenotype (SASP) in senescent fibroblasts; reducing the release of proinflammatory cytokines (Pitozzi et al. 2013) by modulation of mRNA splicing (Latorre et al. 2017). Resveratrol is inexpensive and commercially available but studies in healthy humans are currently limited (Gualdoni et al. 2014). 
Rapamycin (mTOR inhibitor), has emerged as another candidate that mimics the effects of CR. Reduced signalling through mTOR has been associated with increased longevity in invertebrates (Powers et al. 2006), as well as mammalian species (Harrison et al. 2009). Rapamycin is used clinically as an immune suppressant in transplant patients and mTOR mediated immunosuppression is mediated by modulation of effector and regulatory CD4 $\mathrm{T}$ cell subsets (Araki et al. 2011). To date there has been one placebo controlled trial in humans that has used low doses of a m-TOR inhibitor (RAD001) given daily for 6 weeks before the influenza vaccination in older adults. The treatment was shown to increase the antibody response by $20 \%$ for 2 out of 3 strains (Mannick et al. 2014) with few side effects. This drug may have benefits for immunity in old age as well as broader positive health effects through mTOR modulation.

Metformin, a treatment for type 2 diabetes, is able to mimic CR through its activation of AMP kinase and has also been shown to extend lifespan and healthspan in several species including rodents (Martin-Montalvo et al. 2013). Clinical data have also revealed that diabetics taking metformin have significantly lower mortality than diabetics on alternative sulphonyl urea therapies (Campbell et al. 2017). With regard to immunity, recent clinical studies have reported an anti-inflammatory role of metformin (Saisho 2015) and an attenuating effect of metformin on Th17 cell generation and upregulation of Tregs in mice models of arthritis (Son et al. 2014).

\section{Reversal of thymic atrophy}

Thymic capacity is modulated by a range of positive (IL7, KGF, GH) and negative (TNF, IL6) factors (Ventevogel and Sempowski 2013). Thymic regeneration or maintenance would be a rational target for improving immune competence in older adults. Potential mechanisms for thymic regeneration include; IL7 or growth hormone replacement therapy (Aspinall and Mitchell 2008), enhanced keratinocyte growth factor signalling (Seggewiss et al. 2007). Studies carried out in old mice have reported that IL7 therapy reversed thymic atrophy, increased thymopoiesis and raised numbers of naïve $T$ cells in blood (Aspinall et al. 2007; Henson et al. 2005). IL7 administration in preliminary human studies produced an increase in thymic $\mathrm{T}$ cell output and expansion of naïve $\mathrm{T}$ cells in patients with lymphopenia, cancer, chronic viral infections and following transplant (Mackall et al. 2011). IL7 has also been identified as an effective vaccine adjuvant that can augment antigen specific responses post vaccination recombinant lentivector immunised mice (Colombetti et al. 2009). The clinical evidence so far in humans has suggested that rhIL7 is safe with minimal side effects (Lundström et al. 2012), providing compelling evidence for testing rhIL7 as a therapeutic agent to restore thymic output in healthy older adults. Recently IL22 has been identified as another potential target for restoring thymic function due to its ability to promote proliferation and survival of thymic epithelial cells, supporting a microenvironment required for thymopoiesis (Chaudhry et al. 2016). Additionally, exogenous administration of recombinant GH has been reported to promote thymus regrowth in HIV infected adults (Napolitano et al. 2008), though the increased risk of cancer with GH may preclude its long term use.

\section{Statins (HMG-CoA reductase inhibitors)}

The beneficial effect of statins in prevention of cardiovascular events by blocking cholesterol synthesis is well established (Thavendiranathan et al. 2006). Recent studies have shown that statins also possess anti-inflammatory properties and can reduce inflammatory markers, especially IL6 and CRP both during chronic inflammatory conditions (Nawawi et al. 2003; Montecucco and Mach 2009) and also in healthy older individuals (Mora et al. 2010) and this widely used drug may be a promising intervention for combating inflammaging. Our recent data has reported a beneficial of effect of statins in vitro and in vivo in restoring neutrophil migratory accuracy which declines with advancing age (Sapey et al. 2017). That this may be clinically relevant is supported by data showing that patients admitted to hospital with pneumonia who are already on statin medication have reduced mortality compared to those not taking statins (Grudzinska et al. 2017; Bruyere et al. 2014). Additionally, statins are now also recognised as modulators of telomerase activity in study conducted on 230 older adults and can slow telomere shortening, they showed that with every 1 year increment in age a decline by $0.058 \mathrm{~Kb}$ was observed in the no statin group compared with $0.033 \mathrm{~Kb}$ in the statin group (Boccardi et al. 2013). However, a major side effect of using statins that 


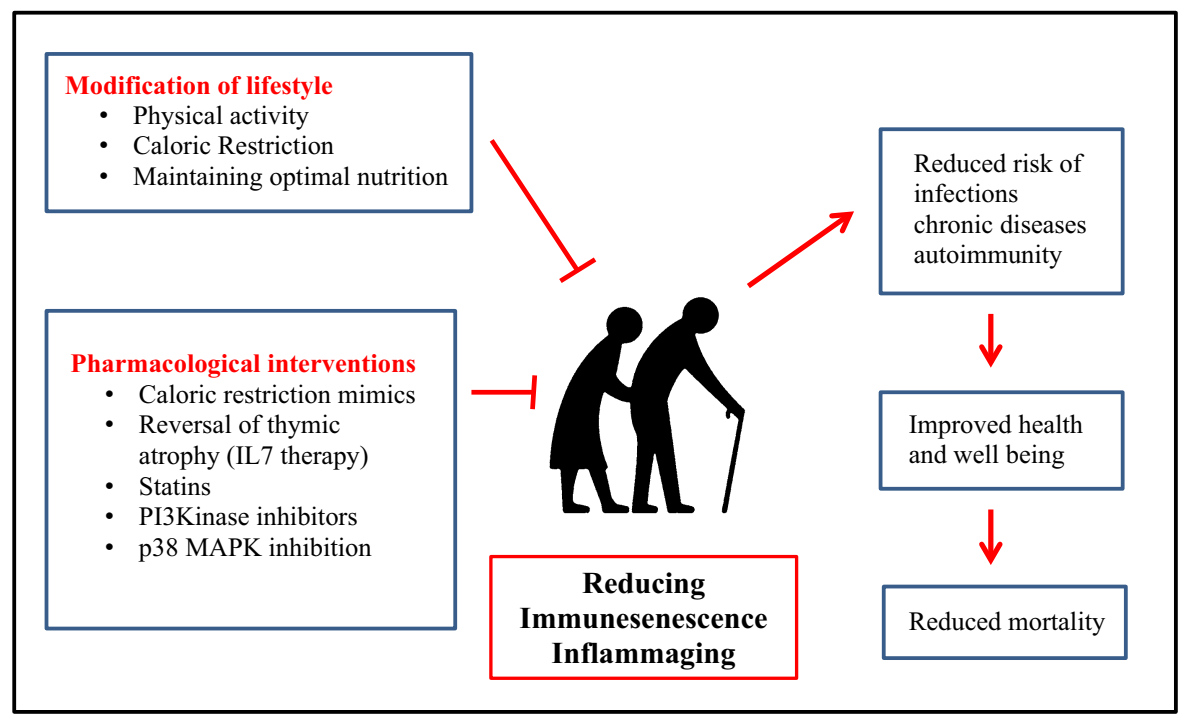

Fig. 3 Intervention strategies targeting immunesenescence and inflammaging

needs to be considered is statin-induced myopathy which is the most common cause of statin discontinuation and has been observed in 10-15\% of statin users (Abd and Jacobson 2011).

\section{PI3kinase inhibitors}

Neutrophil functions such as chemotaxis, phagocytosis and superoxide generation are regulated via phosphoinositide 3 kinase (PI3K) activity (Hannigan et al. 2004). Inaccurate neutrophil chemotaxis in old donors has been associated with increased constitutive $\mathrm{PI} 3 \mathrm{~K} \delta$ signalling and inhibitors of this pathway restore migrational accuracy with no negative effects on other neutrophil functions (Sapey et al. 2014). PI3K blocking therapies offer a new strategy to improve neutrophil function in older adults and might help improve outcomes during infection and reduce inflammation (Naccache and Lefebvre 2014). However, one potential drawback of using PI3K inhibitors is that they might have a negative effect on other immune cells, for instance PI3K is required for DC phagocytosis and migration. Aged DCs in contrast to neutrophils show decreased activation of the PI3K pathway with age (Agrawal et al. 2007) and a further suppression might be detrimental. p38 MAP kinase inhibition

T cells with senescent characteristics increase with age and exhibit constitutive p38 MAPK activation (Henson et al. 2015), with recent data revealing that this is due to formation of a complex between MAP kinases and the sestrin family of proteins which results in kinase activation (Lanna et al. 2017). Furthermore, knockdown of sestrins (Lanna et al. 2017) or inhibition of p38 MAP kinase (Lanna et al. 2014) restored T cell proliferative capacity and old sestrin knockout mice showed improved responses to vaccination compared with wild type mice (Lanna et al. 2017). Clinical trials using p38 inhibitors have been tested for a short time in inflammatory conditions such as rheumatoid arthritis, chronic obstructive pulmonary disease and there were no reports of increased risk of malignancy (Patterson et al. 2014), which is a concern in restoring proliferative capacity more generally. Interestingly TNF $\alpha$ has been shown to inhibit neutrophil migration via activation of the p38MAP kinase pathway (Lokuta and Huttenlocher 2005), suggesting that this pathway could also targeted to restore age associated defects in neutrophil function.

\section{IL15 therapy}

IL15 is known to play a role in regulating immune homeostasis and acts as a lymphocyte survival factor, 
especially for naïve T cells (Wallace et al. 2006). IL15 also plays a critical role in the development and maintenance of NK cells (Cooper et al. 2002) and as stated above NK cell cytotoxicity declines with age (Hazeldine et al. 2012). In vitro studies examining the effect of IL15 on NK cells from acute myeloid leukaemia patients reported an increase in expression of NK cell receptors NKp46 and NKp30 (SanchezCorrea et al. 2016). Clinical evaluation of IL15 in cancer therapy has shown to induce expansion of local $\mathrm{T}$ cells and infiltration of long-lived memory $\mathrm{T}$ cell capacity (Pilipow et al. 2015). These findings suggest the possibility of using cytokine modulation to improve NK cell responses and increase naïve: memory $\mathrm{T}$ cell ratio in older adults.

\section{Conclusion}

The immune system is substantially remodeled with ageing leading to a decline in efficacy with advancing age, resulting in increased risk of chronic diseases, infections, autoimmunity and vaccine failure. Changes in nutrition and lifestyle can be an effective approach towards improving immune outcome in older adults but may be hard to achieve at a population level (Fig. 3). Research in the field of interventions to target immune senescence is gathering pace and improving immune responses such as vaccinations may be used as an early biomarker for anti-ageing effects. A wide range of pharmacological agents with anti-immunesenescence properties have been identified (Fig. 3) and trials with agents such as rapamycin analogs are underway. Thus, immunomodulation represents a promising therapeutic approach to improve the health of older adults.

Open Access This article is distributed under the terms of the Creative Commons Attribution 4.0 International License (http:// creativecommons.org/licenses/by/4.0/), which permits unrestricted use, distribution, and reproduction in any medium, provided you give appropriate credit to the original author(s) and the source, provide a link to the Creative Commons license, and indicate if changes were made.

\section{References}

Abd TT, Jacobson TA (2011) Statin-induced myopathy: a review and update. Expert Opin Drug Saf 10:373-387
Agrawal A, Agrawal S, Cao JN, Su H, Osann K, Gupta S (2007) Altered innate immune functioning of dendritic cells in elderly humans: a role of phosphoinositide 3-kinase-signaling pathway. J Immunol 178:6912-6922

Agrawal S, Ganguly S, Tran A, Sundaram P, Agrawal A (2016) Retinoic acid treated human dendritic cells induce $\mathrm{T}$ regulatory cells via the expression of CD141 and GARP which is impaired with age. Aging 8:1223-1235

Almeida-Oliveira A, Smith-Carvalho M, Porto LC, CardosoOliveira J, Ribeiro Ados S, Falcão RR, Abdelhay E, Bouzas LF, Thuler LC, Ornellas MH, Diamond HR (2011) Age-related changes in natural killer cell receptors from childhood through old age. Hum Immunol 72:319-329

Aprahamian T, Takemura Y, Goukassian D, Walsh K (2008) Ageing is associated with diminished apoptotic cell clearance in vivo. Clin Exp Immunol 152:448-455

Araki K, Ellebedy AH, Ahmed R (2011) TOR in the immune system. Curr Opin Cell Biol 23:707-715

Aspinall R, Mitchell W (2008) Reversal of age-associated thymic atrophy: treatments, delivery, and side effects. Exp Gerontol 43:700-705

Aspinall R, Pido-Lopez J, Imami N, Henson SM, Ngom PT, Morre M, Niphuis H, Remarque E, Rosenwirth B, Heeney JL (2007) Old rhesus macaques treated with interleukin-7 show increased TREC levels and respond well to influenza vaccination. Rejuvenation Res 10:5-17

Bacchetta J, Chun RF, Gales B, Zaritsky JJ, Leroy S, WesselingPerry K, Boregaard N, Rastogi A, Salusky IB, Hewison M (2014) Antibacterial responses by peritoneal macrophages are enhanced following vitamin D supplementation. PLoS ONE 30:9

Bartlett DB, Fox O, McNulty CL, Greenwood HL, Murphy L, Sapey E, Goodman M, Crabtree N, Thøgersen-Ntoumani C, Fisher JP, Wagenmakers AJ, Lord JM (2016) Habitual physical activity is associated with the maintenance of neutrophil migratory dynamics in healthy older adults. Brain Behav Immun 56:12-20

Baylis D, Bartlett DB, Patel HP, Roberts HC (2013) Understanding how we age: insights into inflammaging. Longev Healthspan 2:8

Bigley AB, Rezvani K, Pistillo M, Reed J, Agha N, Kunz H, O'Connor DP, Sekine T, Bollard CM, Simpson RJ (2015) Acute exercise preferentially redeploys NK-cells with a highly-differentiated phenotype and augments cytotoxicity against lymphoma and multiple myeloma target cells. Brain Behav Immun 49:59-65

Boccardi V, Barbieri M, Rizzo MR, Marfella R, Esposito A, Marano L, Paolisso G (2013) A new pleiotropic effect of statins in elderly: modulation of telomerase activity. FASEB J 27:3879-3885

Boge T, Rémigy M, Vaudaine S, Tanguy J, Bourdet-Sicard R, van der Werf S (2009) A probiotic fermented dairy drink improves antibody response to influenza vaccination in the elderly in two randomised controlled trials. Vaccine 27:5677-5684

Boukaiba N, Flament C, Acher S, Chappuis P, Piau A, Fusselier M, Dardenne M, Lemonnier D (1993) A physiological amount of zinc supplementation: effects on nutritional, lipid, and thymic status in an elderly population. Am J Clin Nutr 57:566-572 
Bruyere R, Vigneron C, Prin S, Pechinot A, Quenot JP, Aho S, Papazian L, Charles PE (2014) Impact of prior statin therapy on the outcome of patients with suspected ventilator-associated pneumonia: an observational study. Crit Care 28:18

Campbell JM, Bellman SM, Stephenson MD, Lisy K (2017) Metformin reduces all-cause mortality and diseases of ageing independent of its effect on diabetes control: a systematic review and meta-analysis. Ageing Res Rev 40:31-44

Campbell RA, Franks Z, Bhatnagar A, Rowley JW, Manne BK, Supiano MA, Schwertz H, Weyrich AS, Rondina MT (2018) Granzyme A in human platelets regulates the synthesis of proinflammatory cytokines by monocytes in aging. J Immunol 200:295-304

Campos C, Pera A, Sanchez-Correa B, Alonso C, Lopez-Fernandez I, Morgado S, Tarazona R, Solana R (2014) Effect of age and CMV on NK cell subpopulations. Exp Gerontol 54:130-137

Cavallaro A, Ainis T, Bottari C, Fimiani V (2003) Effect of resveratrol on some activities of isolated and in whole blood human neutrophils. Physiol Res 52:555-562

Cesari M, Penninx BW, Pahor M, Lauretani F, Corsi AM, Rhys Williams G, Guralnik JM, Ferrucci L (2004) Inflammatory markers and physical performance in older persons: the InCHIANTI study. J Gerontol A Biol Sci Med Sci 59:242-248

Chaudhry MS, Velardi E, Dudakov JA, van den Brink MR (2016) Thymus: the next (re)generation. Immunol Rev 271:56-71

Chougnet CA, Thacker RI, Shehata HM, Hennies CM, Lehn MA, Lages CS, Janssen EM (2015) Loss of phagocytic and antigen cross-presenting capacity in aging dendritic cells is associated with mitochondrial dysfunction. J Immunol 195:2624-2632

Chrysohoou C, Panagiotakos DB, Pitsavos C, Das UN, Stefanadis C (2004) Adherence to the Mediterranean diet attenuates inflammation and coagulation process in healthy adults: the ATTICA Study. J Am Coll Cardiol 44:152-158

Clements SJ, Maijo M, Ivory K, Nicoletti C, Carding SR (2017) Age-associated decline in dendritic cell function and the impact of mediterranean diet intervention in elderly subjects. Front Nutr 4:65

Clinthorne JF, Beli E, Duriancik DM, Gardner EM (2013) NK cell maturation and function in C57BL/6 mice are altered by caloric restriction. J Immunol 190:712-722

Cohen HJ, Harris T, Pieper CF (2003) Coagulation and activation of inflammatory pathways in the development of functional decline and mortality in the elderly. Am J Med 15:180-187

Colombetti S, Lévy F, Chapatte L (2009) IL-7 adjuvant treatment enhances long-term tumor-antigen-specific CD8+ T-cell responses after immunization with recombinant lentivector. Blood 113:6629-6637

Colonna-Romano G, Aquino A, Bulati M, Di Lorenzo G, Listi F, Vitello S, Lio D, Candore G, Clesi G, Caruso C (2006) Memory B cell subpopulations in the aged. Rejuvenation Res 9:149-152

Cooper MA, Bush JE, Fehniger TA, VanDeusen JB, Waite RE, Liu Y, Aguila HL, Caligiuri MA (2002) In vivo evidence for a dependence on interleukin 15 for survival of natural killer cells. Blood 100:3633-3638

Das S, Das DK (2007) Anti-inflammatory responses of resveratrol. Inflamm Allergy Drug Targets 6:168-173

Das SK, Roberts SB, Bhapkar MV, Villareal DT, Fontana L, Martin CK, Racette SB, Fuss PJ, Kraus WE, Wong WW, Saltzman E, Pieper CF, Fielding RA, Schwartz AV, Ravussin E, Redman LM, CALERIE-2 Study Group (2017) Body-composition changes in the Comprehensive Assessment of Long-term Effects of Reducing Intake of Energy (CALERIE)-2 study: a 2-y randomized controlled trial of calorie restriction in nonobese humans. Am J Clin Nutr 105:913-927

De la Lastra CA, Villegas I (2005) Resveratrol as an anti-inflammatory and anti-aging agent: mechanisms and clinical implications. Mol Nutr Food Res 49:405-430

Del Giudice G, Goronzy JJ, Grubeck-Loebenstein B, Lambert PH, Mrkvan T, Stoddard JJ, Doherty TM (2017) Fighting against a protean enemy: immunosenescence, vaccines, and healthy aging. NPJ Aging Mech Dis 4:1

do Nascimento MP, Pinke KH, Penitenti M, Ikoma MR, Lara VS (2015) Aging does not affect the ability of human monocyte-derived dendritic cells to phagocytose Candida albicans. Aging Clin Exp Res 27:785-789

Dorshkind K, Montecino-Rodriguez E, Signer RA (2009) The ageing immune system: is it ever too old to become young again? Nat Rev Immunol 9:57-62

Duchateau J, Delepesse G, Vrijens R, Collet H (1981) Beneficial effects of oral zinc supplementation on the immune response of old people. Am J Med 70:1001-1004

Duggal NA, Upton J, Phillips AC, Sapey E, Lord JM (2012) An age-related numerical and functional deficit in CD19(+) CD24(hi) CD38(hi) B cells is associated with an increase in systemic autoimmunity. Aging Cell 12:873-881

Duggal NA, Pollock RD, Lazarus NR, Harridge S, Lord JM (2018) Major features of immunesenescence, including reduced thymic output, are ameliorated by high levels of physical activity in adulthood. Aging Cell 17:2

Duriancik DM, Gardner EM (2016) Energy restriction impairs dendritic cell development in C57BL/6J mice. Mech Ageing Dev 154:9-19

Effros RB, Walford RL, Weindruch R, Mitcheltree C (1991) Influences of dietary restriction on immunity to influenza in aged mice. J Gerontol 46:142-147

Elia M, Jones B, Russell C (2008) Malnutrition in various care settings in the UK: the 2007 Nutrition Screening Week Survey. Clin Med 8:364-365

Enioutina EY, Bareyan D, Daynes RA (2011) A role for immature myeloid cells in immune senescence. J Immunol 186:697-707

Ershler WB, Keller ET (2000) Age-associated increased interleukin-6 gene expression, late-life diseases, and frailty. Annu Rev Med 51:245-270

Falchetti R, Fuggetta MP, Lanzilli G, Tricarico M, Ravagnan G (2001) Effects of resveratrol on human immune cell function. Life Sci 70:81-96

Fontana L, Partridge L (2015) Promoting health and longevity through diet: from model organisms to humans. Cell 161:106-118

Franceschi C, Capri M, Monti D, Giunta S, Olivieri F, Sevini F, Panourgia MP, Invidia L, Celani L, Scurti M, Cevenini E, 
Castellani GC, Salvioli S (2007) Inflammaging and antiinflammaging: a systemic perspective on aging and longevity emerged from studies in humans. Mech Ageing Dev 128:92-105

Franceschi C, Garagnani P, Vitale G, Capri M, Salvioli S (2017) Inflammaging and 'Garb-aging'. Trends Endocrinol Metab 28:199-212

Frasca D, Blomberg BB (2009) Effects of aging on B cell function. Curr Opin Immunol 21:425-430

Fu YR, Yi ZJ, Pei JL, Guan S (2010) Effects of Bifidobacterium bifidum on adaptive immune senescence in aging mice. Microbiol Immunol 54:578-583

Gabrilovich DI, Nagaraj S (2009) Myeloid-derived suppressor cells as regulators of the immune system. Nat Rev Immunol 9:162-174

Gallagher JC (2013) Vitamin D and aging. Endocrinol Metab Clin North Am 42:319-332

Gao X, Xu YX, Janakiraman N, Chapman RA, Gautam SC (2001) Immunomodulatory activity of resveratrol: suppression of lymphocyte proliferation, development of cellmediated cytotoxicity, and cytokine production. Biochem Pharmacol 62:1299-1308

Garbe K, Bratke K, Wagner S, Virchow JC, Lommatzsch M (2012) Plasmacytoid dendritic cells and their Toll-like receptor 9 expression selectively decrease with age. Hum Immunol 73:493-497

Gavazzi G, Krause KH (2002) Ageing and infection. Lancet Infect Dis 11:659-666

Gill HS, Rutherfurd KJ, Cross ML (2001) Dietary probiotic supplementation enhances natural killer cell activity in the elderly: an investigation of age-related immunological changes. J Clin Immunol 21:264-271

Gleeson M, Bishop NC, Stensel DJ, Lindley MR, Mastana SS, Nimmo MA (2011) The anti-inflammatory effects of exercise: mechanisms and implications for the prevention and treatment of disease. Nat Rev Immunol 11:607-615

Goronzy JJ, Weyand CM (2012) Immune aging and autoimmunity. Cell Mol Life Sci 69:1615-1623

Greeley EH, Spitznagel E, Lawler DF, Kealy RD, Segre M (2006) Modulation of canine immunesenescence by lifelong caloric restriction. Vet Immunol Immunopathol 111:287-299

Grudzinska FS, Dosanjh DP, Parekh D, Dancer RC, Patel J, Nightingale P, Walton GM, Sapey E, Thickett DR (2017) Statin therapy in patients with community-acquired pneumonia. Clin Med 17:403-407

Gualdoni GA, Kovarik JJ, Hofer J, Dose F, Pignitter M, Doberer D, Steinberger P, Somoza V, Wolzt M, Zlabinger GJ (2014) Resveratrol enhances TNF- $\alpha$ production in human monocytes upon bacterial stimulation. Biochim Biophys Acta 1840:95-105

Guillemard E, Tondu F, Lacoin F, Schrezenmeir J (2010) Consumption of a fermented dairy product containing the probiotic Lactobacillus casei DN-114001 reduces the duration of respiratory infections in the elderly in a randomised controlled trial. Br J Nutr 103:58-68

Gulcelik NE, Halil M, Ariogul S, Usman A (2013) Adipocytokines and aging: adiponectin and leptin. Minerva Endocrinol 38:203-210

Guo Z, Tilburgs T, Wong B, Strominger JL (2014) Dysfunction of dendritic cells in aged C57BL/6 mice leads to failure of natural killer cell activation and of tumor eradication. Proc Natl Acad Sci USA 111:14199-14204

Guo H, Callaway JB, Ting JP (2015) Inflammasomes: mechanism of action, role in disease, and therapeutics. Nat Med 21:677-687

Haase H, Rink L (2009) The immune system and the impact of zinc during aging. Immun Ageing 12:6-9

Haines CJ, Giffon TD, Lu LS, Lu X, Tessier-Lavigne M, Ross DT, Lewis DB (2009) Human CD4+ T cell recent thymic emigrants are identified by protein tyrosine kinase 7 and have reduced immune function. J Exp Med 206:275-285

Hannigan MO, Huang CK, Wu DQ (2004) Roles of PI3K in neutrophil function. Curr Top Microbiol Immunol 282:165-175

Harrison DE, Strong R, Sharp ZD, Nelson JF, Astle CM, Flurkey K, Nadon NL, Wilkinson JE, Frenkel K, Carter CS, Pahor M, Javors MA, Fernandez E, Miller RA (2009) Rapamycin fed late in life extends lifespan in genetically heterogeneous mice. Nature 460:392-395

Hazeldine J, Hampson P, Lord JM (2012) Reduced release and binding of perforin at the immunological synapse underlies the age-related decline in natural killer cell cytotoxicity. Aging Cell 11:751-759

Hazeldine J, Harris P, Chapple I, Grant M, Greenwood H, Livesey A, Sapey E, Lord J (2014) Impaired neutrophil extracellular trap formation: a novel defect in the innate immune system of aged individuals. Aging Cell 13:690-698

Henson SM, Snelgrove R, Hussell T, Wells DJ, Aspinall R (2005) An IL-7 fusion protein that shows increased thymopoietic ability. J Immunol 175:4112-4118

Henson SM, Macaulay R, Riddell NE, Nunn CJ, Akbar AN (2015) Blockade of PD-1 or p38 MAP kinase signaling enhances senescent human CD8(+) T-cell proliferation by distinct pathways. Eur J Immunol 45:1441-1451

Hewison M (2010) Vitamin D and the immune system: new perspectives on an old theme. Endocrinol Metab Clin North Am 39:365-379

Hoffmann C, Weigert C (2017) Skeletal muscle as an endocrine organ: the role of myokines in exercise adaptations. Cold Spring Harb Perspect Med 1:7-11

Hou PF, Zhu LJ, Chen XY, Qiu ZQ (2017) Age-related changes inCD4+ CD25+ FOXP3 + regulatory $\mathrm{T}$ cells and their relationship with lung cancer. PLoS ONE 12:173

Howard WA, Gibson KL, Dunn-Walters DK (2006) Antibody quality in old age. Rejuvenation Res 9:117-125

Kogut I, Scholz JL, Cancro MP, Cambier JC (2012) B cell maintenance and function in aging. Semin Immunol 24:342-349

Kohut ML, Arntson BA, Lee W, Rozeboom K, Yoon KJ, Cunnick JE, McElhaney J (2004) Moderate exercise improves antibody response to influenza immunization in older adults. Vaccine 22:2298-2306

Laird E, McNulty H, Ward M, Hoey L, McSorley E, Wallace JM, Carson E, Molloy AM, Healy M, Casey MC, Cunningham C, Strain JJ (2014) Vitamin D deficiency is associated with inflammation in older Irish adults. J Clin Endocrinol Metab 99:1807-1815

Lanna A, Henson SM, Escors D, Akbar AN (2014) The kinase p38 activated by the metabolic regulator AMPK and 
scaffold TAB 1 drives the senescence of human T cells. Nat Immunol 15:965-972

Lanna A, Gomes DC, Muller-Durovic B, McDonnell T, Escors D, Gilroy DW, Lee JH, Karin M, Akbar AN (2017) A sestrin-dependent Erk-Jnk-p38 MAPK activation complex inhibits immunity during aging. Nat Immunol 18:354-363

Latorre E, Birar VC, Sheerin AN, Jeynes JCC, Hooper A, Dawe HR, Melzer D, Cox LS, Faragher RGA, Ostler EL, Harries LW (2017) Small molecule modulation of splicing factor expression is associated with rescue from cellular senescence. BMC Cell Biol 18:31

Le Garff-Tavernier M, Béziat V, Decocq J, Siguret V, Gandjbakhch F, Pautas E, Debré P, Merle-Beral H, Vieillard V (2010) Human NK cells display major phenotypic and functional changes over the life span. Aging Cell 9:527-535

Lokuta MA, Huttenlocher A (2005) TNF-alpha promotes a stop signal that inhibits neutrophil polarization and migration via a p38 MAPK pathway. J Leukoc Biol 78:210-219

Long JE, Ring C, Drayson M, Bosch J, Campbell JP, Bhabra J, Browne D, Dawson J, Harding S, Lau J, Burns VE (2012) Vaccination response following aerobic exercise: can a brisk walk enhance antibody response to pneumococcal and influenza vaccinations? Brain Behav Immun 26:680-687

Lord JM (2013) The effect of ageing of the immune system on vaccination responses. Hum Vaccin Immunother 9:1364-1367

Lowder T, Padgett DA, Woods JA (2005) Moderate exercise protects mice from death due to influenza virus. Brain Behav Immun 19:377-380

Lu CC, Chen JK (2010) Resveratrol enhances perforin expression and NK cell cytotoxicity through NKG2D-dependent pathways. J Cell Physiol 223:343-351

Lundström W, Fewkes NM, Mackall CL (2012) IL-7 in human health and disease. Semin Immunol 24:218-224

Lutz CT, Moore MB, Bradley S, Shelton BJ, Lutgendorf SK (2005) Reciprocal age related change in natural killer cell receptors for MHC class I. Mech Ageing Dev 126:722-731

Mackall CL, Fry TJ, Gress RE (2011) Harnessing the biology of IL-7 for therapeutic application. Nat Rev Immunol 11:330-342

Maneerat S, Lehtinen MJ, Childs CE, Forssten SD, Alhoniemi E, Tiphaine M, Yaqoob P, Ouwehand AC, Rastall RA (2014) Consumption of Bifidobacterium lactis $\mathrm{Bi}-07$ by healthy elderly adults enhances phagocytic activity of monocytes and granulocytes. J Nutr Sci 2:10

Mannick JB, Del Giudice G, Lattanzi M, Valiante NM, Praestgaard J, Huang B, Lonetto MA, Maecker HT, Kovarik J, Carson S, Glass DJ, Klickstein LB (2014) mTOR inhibition improves immune function in the elderly. Sci Transl Med 6:268

Martin-Montalvo A, Mercken EM, Mitchell SJ, Palacios HH, Mote PL, Scheibye-Knudsen M, Gomes AP, Ward TM, Minor RK, Blouin MJ, Schwab M, Pollak M, Zhang Y, Yu Y, Becker KG, Bohr VA, Ingram DK, Sinclair DA, Wolf NS, Spindler SR, Bernier M, de Cabo R (2013) Metformin improves healthspan and lifespan in mice. Nat Commun $4: 2192$

Mattison JA, Colman RJ, Beasley TM, Allison DB, Kemnitz JW, Roth GS, Ingram DK, Weindruch R, de Cabo R,
Anderson RM (2017) Caloric restriction improves health and survival of rhesus monkeys. Nat Commun 8:14063

Messaoudi I, Warner J, Fischer M, Park B, Hill B, Mattison J, Lane M, Roth G, Ingram D, Picker L, Douek D, Mori M, Nikolich-Žugich J (2006) Delay of T cell senescence by caloric restriction in aged long-lived nonhuman primates. Proc Natl Acad Sci USA 103:19448-19453

Metcalf TU, Wilkinson PA, Cameron MJ, Ghneim K, Chiang C, Wertheimer AM, Hiscott JB, Nikolich-Zugich J, Haddad EK (2017) Human monocyte subsets are transcriptionally and functionally altered in aging in response to pattern recognition receptor agonists. J Immunol 199:1405-1417

Mitchell WA, Meng I, Nicholson SA, Aspinall R (2006) Thymic output, ageing and zinc. Biogerontology 7:461-470

Mitchell WA, Lang PO, Aspinall R (2010) Tracing thymic output in older individuals. Clin Exp Immunol 161:497-503

Mocchegiani E, Malavolta M (2004) NK and NKT cell functions in immunesenescence. Aging Cell 3:177-184

Mocchegiani E, Muzzioli M, Giacconi R, Cipriano C, Gasparini N, Franceschi C, Gaetti R, Cavalieri E, Suzuki H (2003) Metallothioneins/PARP-1/IL-6 interplay on natural killer cell activity in elderly: parallelism with nonagenarians and old infected humans. Effect of zinc supply. Mech Ageing Dev 124:459-468

Molfino A, Gioia G, Rossi Fanelli F, Muscaritoli M (2014) The role for dietary omega-3 fatty acids supplementation in older adults. Nutrients 6:4058-4073

Molony RD, Malawista A, Montgomery RR (2017a) Reduced dynamic range of antiviral innate immune responses in aging. Exp Gerontol 17:30483-30487

Molony RD, Nguyen JT, Kong Y, Montgomery RR, Shaw AC, Iwasaki A (2017b) Aging impairs both primary and secondary RIG-I signaling for interferon induction in human monocytes. Sci Signal 10:509

Montecucco F, Mach F (2009) Update on statin-mediated antiinflammatory activities in atherosclerosis. Semin Immunopathol 31:127-142

Mora S, Glynn RJ, Hsia J, MacFadyen JG, Genest J, Ridker PM (2010) Statins for the primary prevention of cardiovascular events in women with elevated high-sensitivity C-reactive protein or dyslipidemia: results from the Justification for the Use of Statins in Prevention: an Intervention Trial Evaluating Rosuvastatin (JUPITER) and meta-analysis of women from primary prevention trials. Circulation 121:1069-1077

Moro-García MA, Alonso-Arias R, Baltadjieva M, Fernández Benítez C, Fernández Barrial MA, Díaz Ruisánchez E, Alonso Santos R, Alvarez Sánchez M, Saavedra Miján J, López-Larrea C (2013) Oral supplementation with Lactobacillus delbrueckii subsp. bulgaricus 8481 enhances systemic immunity in elderly subjects. Age 35:1311-1326

Naccache PH, Lefebvre JS (2014) A straight neutrophil path to healthy aging? Blood 123:154-156

Napolitano LA, Schmidt D, Gotway MB, Ameli N, Filbert EL, Ng MM, Clor JL, Epling L, Sinclair E, Baum PD, Li K, Killian ML, Bacchetti P, McCune JM (2008) Growth hormone enhances thymic function in HIV-1-infected adults. J Clin Invest 118:1085-1098

Nawawi H, Osman NS, Annuar R, Khalid BA, Yusoff K (2003) Soluble intercellular adhesion molecule-1 and interleukin- 
6 levels reflect endothelial dysfunction in patients with primary hypercholesterolaemia treated with atorvastatin. Atherosclerosis 169:283-291

Nikolich-Zugich J, Messaoudi I (2005) Mice and flies and monkeys too: caloric restriction rejuvenates the aging immune system of non-human primates. Exp Gerontol 40:884-893

Ong SM, Hadadi E, Dang TM, Yeap WH, Tan CT, Ng TP, Larbi A, Wong SC (2018) The pro-inflammatory phenotype of the human non-classical monocyte subset is attributed to senescence. Cell Death Dis 9:266

Ostan R, Béné MC, Spazzafumo L, Pinto A, Donini LM, Pryen F, Charrouf Z, Valentini L, Lochs H, Bourdel-Marchasson I, Blanc-Bisson C, Buccolini F, Brigidi P, Franceschi C, d'Alessio PA (2016) Impact of diet and nutraceutical supplementation on inflammation in elderly people. Results from the RISTOMED study, an open-label randomized control trial. Clin Nutr 5:812-818

Ouyang X, Yang Z, Zhang R, Arnaboldi P, Lu G, Li Q, Wang W, Zhang B, Cui M, Zhang H, Liang-Chen J, Qin L, Zheng F, Huang B, Xiong H (2011) Potentiation of Th17 cytokines in aging process contributes to the development of colitis. Cell Immunol 266:208-217

Pae M, Meydani SN, Wu D (2012) The role of nutrition in enhancing immunity in aging. Aging Dis 3:91-129

Palmer DB (2013) The effect of age on thymic function. Front Immunol 4:36

Panda A, Qian F, Mohanty S, van Duin D, Newman FK, Zhang L, Chen S, Towle V, Belshe RB, Fikrig E, Allore HG, Montgomery RR, Shaw AC (2010) Age-associated decrease in TLR function in primary human dendritic cells predicts influenza vaccine response. J Immunol 184:2518-2527

Patterson H, Nibbs R, McInnes I, Siebert S (2014) Protein kinase inhibitors in the treatment of inflammatory and autoimmune diseases. Clin Exp Immunol 176:1-10

Pawelec G, Derhovanessian E, Larbi A (2010) Immunosenescence and cancer. Crit Rev Oncol Hematol 75:165-172

Pera A, Campos C, López N, Hassouneh F, Alonso C, Tarazona R, Solana R (2015) Immunosenescence: implications for response to infection and vaccination in older people. Maturitas 82:50-55

Pilipow K, Roberto A, Roederer M, Waldmann TA, Mavilio D, Lugli E (2015) IL15 and T-cell stemness in T-cell-based cancer immunotherapy. Cancer Res 75:5187-5193

Pillai PS, Molony RD, Martinod K, Dong H, Pang IK, Tal MC, Solis AG, Bielecki P, Mohanty S, Trentalange M, Homer RJ, Flavell RA, Wagner DD, Montgomery RR, Shaw AC, Staeheli P, Iwasaki A (2016) Mx1 reveals innate pathways to antiviral resistance and lethal influenza disease. Science 352:463-466

Pitozzi V, Mocali A, Laurenzana A, Giannoni E, Cifola I, Battaglia C, Chiarugi P, Dolara P, Giovannelli L (2013) Chronic resveratrol treatment ameliorates cell adhesion and mitigates the inflammatory phenotype in senescent human fibroblasts. J Gerontol A Biol Sci Med Sci 68:371-381

Plowden J, Renshaw-Hoelscher M, Gangappa S, Engleman C, Katz JM, Sambhara S (2004) Impaired antigen-induced $\mathrm{CD} 8+\mathrm{T}$ cell clonal expansion in aging is due to defects in antigen presenting cell function. Cell Immunol 229:86-92
Powers RW, Kaeberlein M, Caldwell SD, Kennedy BK, Fields S (2006) Extension of chronological life span in yeast by decreased TOR pathway signalling. Genes Dev 15:174-184

Prasad AS (2000) Effects of zinc deficiency on Th1 and Th2 cytokine shifts. J Infect Dis 182:62-68

Prasad AS (2009) Zinc: role in immunity, oxidative stress and chronic inflammation. Curr Opin Clin Nutr Metab Care 12:646-652

Prasad AS, Beck FW, Bao B, Fitzgerald JT, Snell DC, Steinberg JD, Cardozo LJ (2007) Zinc supplementation decreases incidence of infections in the elderly: effect of zinc on generation of cytokines and oxidative stress. Am J Clin Nutr 85(3):837-844

Qian F, Wang X, Zhang L, Chen S, Piecychna M, Allore H, Bockenstedt L, Malawista S, Bucala R, Shaw AC, Fikrig E, Montgomery RR (2012) Age-associated elevation in TLR5 leads to increased inflammatory responses in the elderly. Aging Cell 11:104-110

Qian F, Guo X, Wang X, Yuan X, Chen S, Malawista SE, Bockenstedt LK, Allore HG, Montgomery RR (2014) Reduced bioenergetics and Toll-like receptor 1 function in human polymorphonuclear leukocytes in aging. Aging 6:131-139

Radford DJ, Wang K, McNelis JC, Taylor AE, Hechenberger G, Hofmann J, Chahal H, Arlt W, Lord JM (2010) Dehydroepiandrosterone sulfate directly activates protein kinase C-beta to increase human neutrophil superoxide generation. Mol Endocrinol 24:813-821

Ravussin E, Redman LM, Rochon J, Das SK, Fontana L, Kraus WE, Romashkan S, Williamson DA, Meydani SN, Villareal DT, Smith SR, Stein RI, Scott TM, Stewart TM, Saltzman E, Klein S, Bhapkar M, Martin CK, Gilhooly CH, Holloszy JO, Hadley EC, Roberts SB, CALERIE Study Group (2015) A 2-year randomized controlled trial of human caloric restriction: feasibility and effects on predictors of health span and longevity. J Gerontol A Biol Sci Med Sci 70:1097-1104

Rink L, Gabriel P (2000) Zinc and the immune system. Proc Nutr Soc 59:541-552

Ritz BW, Gardner EM (2006) Malnutrition and energy restriction differentially affect viral immunity. J Nutr 136:1141-1144

Ritz BW, Aktan I, Nogusa S, Gardner EM (2008) Energy restriction impairs natural killer cell function and increases the severity of influenza infection in young adult male C57BL/6 mice. J Nutr 138:2269-2275

Ross R, Bradshaw AJ (2009) The future of obesity reduction: beyond weight loss. Nat Rev Endocrinol 5:319-325

Sagiv A, Biran A, Yon M, Simon J, Lowe SW, Krizhanovsky V (2013) Granule exocytosis mediates immune surveillance of senescent cells. Oncogene 32:1971-1977

Sagiv A, Burton DG, Moshayev Z, Vadai E, Wensveen F, BenDor S, Golani O, Polic B, Krizhanovsky V (2016) NKG2D ligands mediate immunosurveillance of senescent cells. Aging 8:328-344

Saisho Y (2015) Metformin and inflammation: its potential beyond glucose lowering effect. Endocr Metab Immun Disord Drug Targets 15:196-205

Sanchez-Correa B, Campos C, Pera A, Bergua JM, Arcos MJ, Bañas H, Casado JG, Morgado S, Duran E, Solana R, 
Tarazona R (2016) Natural killer cell immunosenescence in acute myeloid leukaemia patients: new targets for immunotherapeutic strategies? Cancer Immunol Immunother 65:453-463

Sapey E, Greenwood H, Walton G, Mann E, Love A, Aaronson N, Insall RH, Stockley RA, Lord JM (2014) Phosphoinositide 3-kinase inhibition restores neutrophil accuracy in the elderly: toward targeted treatments for immunosenescence. Blood 123:239-248

Sapey E, Patel JM, Greenwood HL, Walton GM, Hazeldine J, Sadhra C, Parekh D, Dancer RCA, Nightingale P, Lord JM, Thickett DR (2017) Pulmonary infections in the elderly lead to impaired neutrophil targeting, which is improved by simvastatin. Am J Respir Crit Care Med 196:1325-1336

Sasaki S, Matsuura T, Takahashi R, Iwasa T, Watanabe H, Shirai K, Nakamoto H, Goto S, Akita S, Kobayashi Y (2013) Effects of regular exercise on neutrophil functions, oxidative stress parameters and antibody responses against 4-hydroxy-2-nonenal adducts in middle aged humans. Exerc Immunol Rev 19:60-71

Sawalha AH, Kovats S (2008) Dehydroepiandrosterone in systemic lupus erythematosus. Curr Rheumatol Rep 10:286-291

Schmader K (2001) Herpes zoster in older adults. Clin Infect Dis 32:1481-1486

Sebastián C, Espia M, Serra M, Celada A, Lloberas J (2005) MacrophAging: a cellular and molecular review. Immunobiology 210:121-126

Seggewiss R, Loré K, Guenaga FJ, Pittaluga S, Mattapallil J, Chow CK, Koup RA, Camphausen K, Nason MC, MeierSchellersheim M, Donahue RE, Blazar BR, Dunbar CE, Douek DC (2007) Keratinocyte growth factor augments immune reconstitution after autologous hematopoietic progenitor cell transplantation in rhesus macaques. Blood 110:441-449

Seidler S, Zimmermann HW, Bartneck M, Trautwein C, Tacke F (2010) Age-dependent alterations of monocyte subsets and monocyte-related chemokine pathways in healthy adults. BMC Immunol 21:11-30

Sempowski GD, Hale LP, Sundy JS, Massey JM, Koup RA, Douek DC, Patel DD, Haynes BF (2000) Leukemia inhibitory factor, oncostatin M, IL-6, and stem cell factor mRNA expression in human thymus increases with age and is associated with thymic atrophy. $\mathbf{J}$ Immunol 164:2180-2187

Shepherd SO, Wilson OJ, Taylor AS, Thøgersen-Ntoumani C, Adlan AM, Wagenmakers AJ, Shaw CS (2015) Low-volume high-intensity interval training in a gym setting improves cardio-metabolic and psychological health. PLoS ONE 24:10

Shimizu K, Kimura F, Akimoto T, Akama T, Tanabe K, Nishijima T, Kuno S, Kono I (2008) Effect of moderate exercise training on T-helper cell subpopulations in elderly people. Exerc Immunol Rev 14:24-37

Shinkai S, Kohno H, Kimura K, Komura T, Asai H, Inai R, Oka K, Kurokawa Y, Shephard R (1995) Physical activity and immune senescence in men. Med Sci Sports Exerc 27:1516-1526

Siegrist CA, Aspinall R (2009) B-cell responses to vaccination at the extremes of age. Nat Rev Immunol 9:185-194
Silva LC, de Araújo AL, Fernandes JR, Matias Mde S, Silva PR, Duarte AJ, Garcez Leme LE, Benard G (2016) Moderate and intense exercise lifestyles attenuate the effects of aging on telomere length and the survival and composition of $\mathrm{T}$ cell subpopulations. Age 38:24

Singh T, Newman AB (2011) Inflammatory markers in population studies of aging. Ageing Res Rev 10:319-329

Solana R, Campos C, Pera A, Tarazona R (2014) Shaping of NK cell subsets by aging. Curr Opin Immunol 29:56-61

Solerte SB, Fioravanti M, Vignati G, Giustina A, Cravello L, Ferrari E (1999) Dehydroepiandrosterone sulfate enhances natural killer cell cytotoxicity in humans via locally generated immunoreactive insulin-like growth factor I. J Clin Endocrinol Metab 84:3260-3267

Son HJ, Lee J, Lee SY, Kim EK, Park MJ, Kim KW, Park SH, Cho ML (2014) Metformin attenuates experimental autoimmune arthritis through reciprocal regulation of Th17/Treg balance and osteoclastogenesis. Mediators Inflamm 10:973-986

Spaulding CC, Walford RL, Effros RB (1997) The accumulation of non-replicative, non-functional, senescent $\mathrm{T}$ cells with age is avoided in calorically restricted mice by an enhancement of $\mathrm{T}$ cell apoptosis. Mech Ageing Dev 93:25-33

Sridharan A, Esposo M, Kaushal K, Tay J, Osann K, Agrawal S, Gupta S, Agrawal A (2011) Age-associated impaired plasmacytoid dendritic cell functions lead to decreased CD4 and CD8 T cell immunity. Age 33:363-376

Steensberg A, Fischer CP, Keller C, Møller K, Pedersen BK (2003) IL-6 enhances plasma IL-1ra, IL-10, and cortisol in humans. Am J Physiol Endocrinol Metab 285:433-437

Straub RH, Konecna L, Hrach S, Rothe G, Kreutz M, Schölmerich J, Falk W, Lang B (1998) Serum dehydroepiandrosterone (DHEA) and DHEA sulfate are negatively correlated with serum interleukin-6 (IL-6), and DHEA inhibits IL-6 secretion from mononuclear cells in man in vitro: possible link between endocrinosenescence and immunosenescence. J Clin Endocrinol Metab 83:2012-2017

Strioga M, Pasukoniene V, Characiejus D (2011) CD8+ CD28 - and CD8 + CD57+ T cells and their role in health and disease. Immunology 134:17-32

Suchánek O, Podrazil M, Fischerová B, Bočínská H, Budínský V, Stejskal D, Spíšek R, Bartůňková J, Kolář P (2010) Intensive physical activity increases peripheral blood dendritic cells. Cell Immunol 266:40-45

Tang D, Tao S, Chen Z, Koliesnik IO, Calmes PG, Hoerr V, Han B, Gebert N, Zörnig M, Löffler B, Morita Y, Rudolph KL (2016) Dietary restriction improves repopulation but impairs lymphoid differentiation capacity of hematopoietic stem cells in early aging. J Exp Med 213:535-553

Tenover JS, Matsumoto AM, Plymate SR, Bremner WJ (1987) The effects of aging in normal men on bioavailable testosterone and luteinizing hormone secretion: response to clomiphene citrate. J Clin Endocrinol Metab 65:1118-1126

Thavendiranathan P, Bagai A, Brookhart MA, Choudhry NK (2006) Primary prevention of cardiovascular diseases with statin therapy: a meta-analysis of randomized controlled trials. Arch Intern Med 166:2307-2313 
Thomas CM, Versalovic J (2010) Probiotics-host communication: modulation of signaling pathways in the intestine. Gut Microbes 1:148-163

Tian Z, Sun R, Wei H, Gao B (2002) Impaired natural killer (NK) cell activity in leptin receptor deficient mice: leptin as a critical regulator in NK cell development and activation. Biochem Biophys Res Commun 298:297-302

Timmerman KL, Flynn MG, Coen PM, Markofski MM, Pence BD (2009) Exercise training-induced lowering of inflammatory $(\mathrm{CD} 14+\mathrm{CD} 16+)$ monocytes: a role in the antiinflammatory influence of exercise? J Leukoc Biol 84:1271-1278

Tung BT, Rodríguez-Bies E, Talero E, Gamero-Estévez E, Motilva V, Navas P, López-Lluch G (2015) Anti-inflammatory effect of resveratrol in old mice liver. Exp Gerontol 64:1-7

Turner JE, Spielmann G, Wadley AJ, Aldred S, Simpson RJ, Campbell JP (2016) Exercise-induced B cell mobilisation: preliminary evidence for an influx of immature cells into the bloodstream. Physiol Behav 164:376-382

Uciechowski P, Kahmann L, Plümäkers B, Malavolta M, Mocchegiani E, Dedoussis G, Herbein G, Jajte J, Fulop T, Rink L (2008) TH1 and TH2 cell polarization increases with aging and is modulated by zinc supplementation. Exp Gerontol 43:493-498

Vanherwegen AS, Gysemans C, Mathieu C (2017) Regulation of immune function by vitamin D and its use in diseases of immunity. Endocrinol Metab Clin 46:1061-1094

Ventevogel MS, Sempowski GD (2013) Thymic rejuvenation and aging. Curr Opin Immunol 25:516-522

Vieira-Potter VJ (2014) Inflammation and macrophage modulation in adipose tissues. Cell Microbiol 16:1484-1492

Walker C, Black RE (2004) Zinc and the risk for infectious disease. Ann Rev Nutr 24:255-275

Wallace DL, Bérard M, Soares MV, Oldham J, Cook JE, Akbar AN, Tough DF, Beverley PC (2006) Prolonged exposure of naïve $\mathrm{CD} 8+\mathrm{T}$ cells to interleukin-7 or interleukin-15 stimulates proliferation without differentiation or loss of telomere length. Immunology 119:243-253

Wang Q, Westra J, van der Geest KS, Moser J, Bijzet J, Kuiper T, Lorencetti PG, Joosten LA, Netea MG, Heeringa P, Brouwer E, Boots AM (2016) Reduced levels of cytosolic DNA sensor AIM2 are associated with impaired cytokine responses in healthy elderly. Exp Gerontol 78:39-46
Weng NP, Akbar AN, Goronzy J (2009) CD28(-) T cells: their role in the age-associated decline of immune function. Trends Immunol 30:306-312

Wenisch C, Patruta S, Daxbock F, Krause R, Horl W (2000) Effect of age on human neutrophil function. J Leukoc Biol 67:40-45

Willcox BJ, Willcox DC, Todoriki H, Fujiyoshi A, Yano K, He Q, Curb JD, Suzuki M (2007) Caloric restriction, the traditional Okinawan diet, and healthy aging: the diet of the world's longest-lived people and its potential impact on morbidity and life span. Ann N Y Acad Sci 1114:434-455

Willcox BJ, Willcox DC, Suzuki M (2017) Demographic, phenotypic, and genetic characteristics of centenarians in Okinawa and Japan: part 1-centenarians in Okinawa. Mech Ageing Dev 165:75-79

Willette AA, Bendlin BB, McLaren DG, Canu E, Kastman EK, Kosmatka KJ, Xu G, Field AS, Alexander AL, Colman RJ, Weindruch RH, Coe CL, Johnson SC (2010) Age-related changes in neural volume and microstructure associated with interleukin- 6 are ameliorated by a calorie-restricted diet in old rhesus monkeys. Neuroimage 51:987-994

World Health Organisation (2010) Global recommendations on physical activity for health. World Health Organisation, Geneva

Yaffe K, Lindquist K, Penninx BW, Simonsick EM, Pahor M, Kritchevsky S, Launer L, Kuller L, Rubin S, Harris T (2003) Inflammatory markers and cognition in well-functioning African-American and white elders. Neurology 61:76-80

Yan H, Kuroiwa A, Tanaka H, Shindo M, Kiyonaga A, Nagayama A (2001) Effect of moderate exercise on immune senescence in men. Eur J Appl Physiol 86:105-111

Yang H, Youm YH, Dixit VD (2009) Inhibition of thymic adipogenesis by caloric restriction is coupled with reduction in age-related thymic involution. J Immunol 183:3040-3052

Yin K, Agrawal DK (2014) Vitamin D and inflammatory diseases. J Inflamm Res 29:69-87

Zakrzewski JL, Kochman AA, Lu SX, Terwey TH, Kim TD, Hubbard VM, Muriglan SJ, Suh D, Smith OM, Grubin J, Patel N, Chow A, Cabrera-Perez J, Radhakrishnan R, Diab A, Perales MA, Rizzuto G, Menet E, Pamer EG, Heller G, Zúñiga-Pflücker JC, Alpdogan O, van den Brink MR (2006) Adoptive transfer of T-cell precursors enhances $\mathrm{T}$-cell reconstitution after allogeneic hematopoietic stem cell transplantation. Nat Med 12:1039-1047 